\title{
Interaction of Blood Proteins with Solid Surfaces
}

R. R. Stromberg, B. W. Morrissey, L. E. Smith, W. H. Grant, and R. E. DehI

Polymers Division

Institute for Materials Research

National Bureau of Standards

Washington, D. C. 20234

March 5, 1976

Annual Report for Period

November 1, 1974 - October 31, 1975

\section{Prepared for}

Biomaterials Program

Division of Blood Diseases and Resources

National Heart and Lung Institute

National Institutes of Health

Bethesda, Maryland 20014

Interagency Reimbursable Agreement 
NOTICE

This report was prepared as an account of work sponsored by the National Heart and Lung Institute. It is not to be construed as a report, opinion, or recommendation of the National Heart and Lung Institute. It w111 be available from the National Technical Information Service, 5285 Port Royal Road, Springfield, Virginia 22151.

Certain commercial equipment is 1dentified in this report in order to adequately specify the experimental procedure. In no case does such identification imply recommendation or endorsement by the National Bureau of Standards nor does it imply that the equipment identified is the best available. 


\section{INTERACTION OF BLOOD PROTEINS WITH SOLID SURFACES}

R. R. Stromberg, B. W. Morrissey, L. E. Smith, W. H. Grant, and R. E. DehI

Polymers Division

Institute for Materials Research

National Bureau of Standards

Washington, D. C. 20234

March 5, 1976

Annual Report for Period

November 1, 1974 - Octoer 31, 1975

Prepared for

Biomaterials Program

Division of Blood Diseases and Resources

National Hear and Lung Institute

National Institutes of Health

Bethesda, Maryland 20014

Interagency Reimbursable Agreement

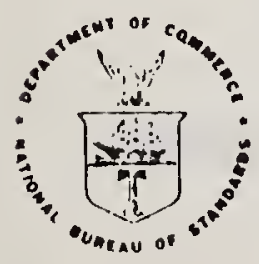

U.S. DEPARTMENT OF COMMERCE, Elliot L. Richardson, Secretary James A. Baker, III, Under Secrotary

Dr. Betsy Ancker-Johnson, Assistant Secrotary for Scionce and Tochnology

NATIONAL BUREAU OF STANDARDS, Ernest Ambler, Acting Director 

ABSTRACT . . . . . . . . . . . . . . . . . . . 1

SUMMARY . . . . . . . . . . . . . . . . . . . . . 11

INTRODUCTION . . . . . . . . . . . . . . . . . . . 1

EXPERIMENTAL . . . . . . . . . . . . . . . . . . . . 2

Protein Purity . . . . . . . . . . . . . . . . . 2

Flbrinogen . . . . . . . . . . . . . . . . 2

Albumin . . . . . . . . . . . . . . . . . . 2

$\gamma$-Globulin . . . . . . . . . . . . . . . . 2

B-Lactoglobulin . . . . . . . . . . . . . . 2

Ellipsometry . . . . . . . . . . . . . . . . . . 2

Radiotracers . . . . . . . . . . . . . . . . 3

RESULTS AND DISCUSSION • . . . . . . . . . . . . . . . . 4

EXAMINATION OF NHLI BIOMATERIAL PROGRAM MATERIALS . . . . . . . 4

Polyether urethane (Stanford Research Institute) . . . . 4

Ion-Plated carbon (General Atomlcs Corp.) . . . . . . . 7

Poly (vinyl acetate-co-crotonic acid) (Union Carbide) . . . 8

Polyacrylamide hydrogels (Franklin Research Institute) - . 8

Glow discharge coatings (Research Triangle Institute) 。 8

FACTORS INDUCING CONFORMATION CHANGES . . . . . . . . . . . 9

Applied Potential . . . . . . . . . . . . . 9

Surface Concentration . . . . . . . . . . . . 10

Adsorption Time . . . . . . . . . . . . . . . 17

Denaturing Media... . . . . . . . . . . . . 18

RADIOTRACER RATE STUDIES . . . . . . . . . . . . . 21

Measurement . . . . . . . . . . . . . . 21

Desorption and Exchange . . . . . . . . . . . . . 22

Silicone Rubber . . . . . . . . . . . . . 27

REFERENCES . . . . . . . . . . . . . . . . . . . 29 

Figure 1: Adsorbance of Human Fibrinogen on SRI Polyether

Urethane 3-2000-1-E . . . . . . . . . . . . 5

Figure 2: Extension of Adsorbed Human Fibrinogen on SRI

Polyether Urethane 3-2000-1-E . . . . . . . . 6

Figure 3: Stability of refractive index components of platinum in $0.15 \mathrm{~N} \mathrm{NaCl}$ with applied potentials... . . . . 11

Figure 4: Instability of apparent optical density of germanium in $0.15 \mathrm{~N} \mathrm{NaCl}$. . . . . . . . . . . . . . 12

Figure 5: Instability of apparent optical density of germanium in $0.15 \mathrm{~N} \mathrm{NaCl}$ with applied potentials . . . . . . 13

Figure 6: Extension and adsorbance of bovine $\gamma$-globulin on fused silica . . . . . . . . . . . . . 16

Figure 7: Effect of urea on adsorbance of human fibrinogen adsorbed on polyethylene . . . . . . . . . . . 19

Figure 8: Effect of urea on extension of human fibrinogen adsorbed on polyethylene .. . . . . . . . . 20

Figure 9: Desorption and exchange of fibrinogen adsorbed on polyethylene with fibrinogen . . . . . . . . . . 24

Figure 10: Desorption of human serum albumin from polyethylene and chrome into buffer . . . . . . . . . . 25

Figure 11: Desorption of $\mathrm{HSA}^{-125}$ I from polyethylene into $8 \mathrm{M}$ buffered urea... . . . . . . . . . . . 26

Figure 12: Rate of Adsroption of HSA- ${ }^{131}$ I on Silicone Rubber . . . 28 TABLES

Table I: $\gamma$-Globulin Adsorbed on Silica . . . . . . . . . 15

Table II: Apparent Adsorbance as a Function of Specific Activity of HSA-125 I Solution .. . . . . . . 23 



\section{ABSTRACT}

The overall objective of this investigation is to help characterize materials used for implants in the cardiovascular system and to develop test methods to aid in the selection of the most useful materials. The focus of the work has been an investigation of the adsorption of blood proteins on surfaces with special emphasis on changes in conformation occurring upon adsorption. An important component has been an ellipsometric examination of materials produced by contractors of the NHLI Biomaterials Program that were considered to be of potential clinical value. In contrast to the behavior of serum albumin and prothrombin, conformational changes in $\gamma$-globulin and $\beta$-lactoglobulin occurring as a consequence of changing surface population were previously reported and were confirmed during this reporting period. An investigation of conformational changes at very short adsorption time was initiated. Adsorption, desorption and exchange of adsorbed protein with protein in solution was studied. The results indicate strong hydrophobic bonding between the protein and the synthetic polymer surface. 


\section{SUMMARY}

The goal of this investigation has been to further characterize the synthetic materials used for implants in the cardiovascular system and to develop test methods to ald in the selection of the most useful materials. The focus of the work has been directed at changes that occur when certain blood proteins interact with a foreign material.

The proteins studied have been the same as those used in earlier phases of this investigation; fibrinogen, albumin, $\gamma$-globulin and $\beta$-lactoglobulin. They have been selected because of their importance to the clotting process, abundance in the blood plasma, or as a model to better understand a more complex situation. Repurification or special labeling have been carried out as necessary.

An important component of this effort has been an investigation in our laboratory of materials produced by contractors of the NHLI Biomaterials Program and considered by the Project officer to be of potential clinical value. The objective is to attempt to find a direct correlation between the adsorption behavior of blood proteins and thrombogenicity of a material. Such a correlation could, of course, be developed into a useful test method. Materials produced by five contractors were examined by means of ellipsometry. Results for the adsorption of fibrinogen on a polyether urethane prepared by Stanford Research Institute were quite promising in that the measured fibrinogen adsorbances and extensions were in agreement with those measured on other materials of simflar surface energy.

The in situ quantitative ellipsometric investigation of the relationship between surface potential and protein-surface interaction was extended to germanium. This is a material of special interest because of its applicability to internal reflection spectroscopy in the infrared regions. It was found that the germanium is unstable compared to platinum, in the presence of $\mathrm{NaCl}$ both with and without applied potential. This appears to cast doubt regarding its use in spectroscopic studies under these conditions.

Work on the effect of surface concentration on the conformation of adsorbed proteins included some additional measurements of the extension and number of carbonyl contacts for $\gamma$-globulin and $\beta$-lactoglobulin. The conclusions were essentially the same as those previously reported, 1.e. conformational changes in these two proteins apparently occur as a result of increased surface population, in contrast to no change for serum albumin or prothrombin. Measurements of changes in conformation of the adsorbing molecule at very short adsorption times $(-28)$ has been inftiated with an automatic ellipsometer. Techniques are being developed and some preliminary results have been obtained.

The adsorption and desorption of proteins on polyethylene has been investigated ellipsometrically and by use of radiotracers. In addition, a serious examination of artifacts resulting from the labeling of proteins with radioactive lodine has been made. The polyethylene is quite interesting in that no desorption into buffer or exchange with protein in solution could be measured from this low energy surface, implying strong hydrophobic bonding between the protein and the synthetic polymer. 


\section{INTRODUCTION}

The adsorption of plasma proteins is the first in a complex series of events that occurs when a synthetic material is placed in the cardiovascular system. It is known that this protein adsorption can alter the course of subsequent reactions at the implant surface but the mechanism by which this occurs is not well understood. If the detalled behavior of protelns adsorbed at the solid surface were known and capable of control, the fate of artificial materials placed in body could be predicted with greater certainty and more successful materials could, perhaps, be designed. The investigation is directed toward the identification of factors capable of affecting protein adsorption and the development of a description of the changes that occur in the protein upon interaction with a surface.

This approach to the problem of design criteria and test methods for biomaterials has been developed more extensively in previous reports and experimental techniques have also been described in detall. This report discusses our studies of the effect of applied surface potential, population of protein on the adsorbing surface, and denaturing media on the conformation of the adsorbed protein. We have continued our investigation into the use of radiotracers to measure the adsorption behavior of proteins and discuss a number of difficulties with their application. Several materials prepared especially for the Blomaterials Program have been examined. 


\section{Protein Purity}

\section{Fibrinogen}

Bovine and human flbrinogen were repurified in our laboratories by the Laki (1) and Batt (2) methods, respectively, to yield a product that is greater than $96.7 \%$ clottable. (The theoretical maximum 1s 97\%).

\section{Albumin}

The human and bovine serum albumin were obtained as four times recrystallized material with an electrophoretic purity of $100 \%$ as specified by the supplier.

$x-$ Globulin

This material is recrystallized and has purity greater than $95 \%$ as reported by the supplier.

\section{$\underline{\beta \text {-Lactoglobulin }}$}

Bovine $\beta$-lactoglobulin, three times recrystallized, was used as received.

\section{Ellipsometry}

The general experimental technique of ellipsometry and methods of data analysis have been described in previous reports $(3,4)$. The only changes in these procedures were those necessitated by investigations designed to measure conformation changes at very short adsorption times. The optical constants of the surface are obtained in the usual manner, with measurements made under buffers. In order to make measurements in the initial stages of the adsorption process, it is necessary to expose the "bare" surface to the protein solution in as short a time period as possible. At the same time the introduction of artifacts such as denatured material must also be avolded. For the preliminary adsorption experiments with the automatic ellipsometer described in this report, a straightforward method of introducing the protein solutions was adopted.

After determining the optical constants of the substrate under buffer solution, the solution was withdrawn from the ellipsometer cell as completely as possible with a syringe, leaving a thin film of solution on top of the (hydrophilic) substrate. A premeasured quantity of filtered protein solution was then quickly poured into the cell. Since the solution is introduced in a highly turbulent manner, it should $\mathrm{mix}$ rapidly with any residual buffer solution in the cell. This technique allowed measurement of the ellipsometric parameters in less than 2 seconds after the solution pouring was begun. The resultant changes in the parameters were smooth and monotonic throughout the total observation times, which ranged up to 3 hours. 
Human serum albumin (HSA) labeled with radloactive iodine was secured as follows:

1. $\mathrm{HSA}^{131} \mathrm{I}$ and $\mathrm{HSA}^{125} \mathrm{I}$, injection quality diagnostic grade from Squibb Pharmaceutical Co., as a $1 \%$ solution 1 in $1.6 \% \mathrm{NaH}_{2} \mathrm{PO}_{4} \cdot \mathrm{H}_{2} \mathrm{O}$ and $0.16 \%$ $\mathrm{Na}_{2} \mathrm{HPO}_{4}$ buffer.

2. HSA- ${ }^{125}$ I was labeled in our laboratory using the ICl method of McFarlane (5).

The solvent for all experiments was $0.1 \mathrm{M}$ phosphate buffer with a pH of 7.4. Procedures for cleaning the substrates and determining the amount of labeled material adsorbed or remalning after desorption were the same as previously desclrbed (3). 
An important part of this investigation is the direct application of the surface techniques used in our laboratory to materials produced by contractors to the NHLI Biomaterials Program. This involves an examination of some of the surface properties of a material and, when feasible, an investigation of the interaction of blood proteins with it. Because of its importance in the clotting sequence and because of the body of information already available, fibrinogen was selected for inter-comparison purposes. The objective was to attempt to find some direct correlation between the adsorption behavior of blood proteins and the thrombogenic behavior of clinically promising materials. In order to demonstrate such a relationship, it is necessary to examine materials with poor as well as those with desirable characteristics.

The results obtained on materials examined to date are described briefly below. They were, in general, used "as received". It should be recognized that for most of the materials this information given here does not represent a completed investigation. In some cases our studies are still in progress. In other cases, we are attempting to adapt our techniques to a "new" type of surface or the contractor, who is developing a new material, still is in the process or making significant changes to his product. The materials to be investigated are selected collaboratively with the Project officer.

\section{Polyether Urethane, 3-2000-1-E (Stanford Research Institute)}

Samples of polyether urethane, 3-2000-1-E were obtained from Dr. Brauman of the Stanford Research Institute (SRI) for ellipsometric studies of protein adsorption. These samples invariably turned white and opaque after a few hours under water or buffer. Not withstanding this change in appearance, the refractive index of the SRI polyurethane did not change significantly and the material was stable for several days. In addition, good agreement was found with the refractive index (1.48) determined in air on the same material.

The molecular extension and adsorbance of fibrinogen adsorbed on SRI material 3-2000-1-E were determined at $\mathrm{pH} 7.4$ in situ. As shown in Figures 1 and 2 , there are no changes in adsorbance and only a slight increase in extension of purified human fibrinogen over the time interval of 5 to 150 minutes following the introduction of the protein solution at a concentration of $3.0 \mathrm{mg} / \mathrm{ml}$. The adsorbance of approximately $4 \mathrm{mg} / \mathrm{m}^{2}$ and an extension of $50 \mathrm{~nm}$ may be compared with the previous study (4) of fibrinogen adsorption on a variety of materials ranging in surface energy from platinum to polyethylene. In all previous cases, the adsorbance was found to lie between 3.7 and $5.4 \mathrm{mg} / \mathrm{m}^{2}$. The molecular extension varied from $23 \mathrm{~nm}$ on the high energy platinum surface, to $43 \mathrm{~nm}$ on carbon and $59 \mathrm{~nm}$ on the relatively low energy polyethylene surface. The extension of fibrinogen on the polyether urethane therefore lies between carbon and polyethylene, as one would predict based on its critical surface tension for wetting. 


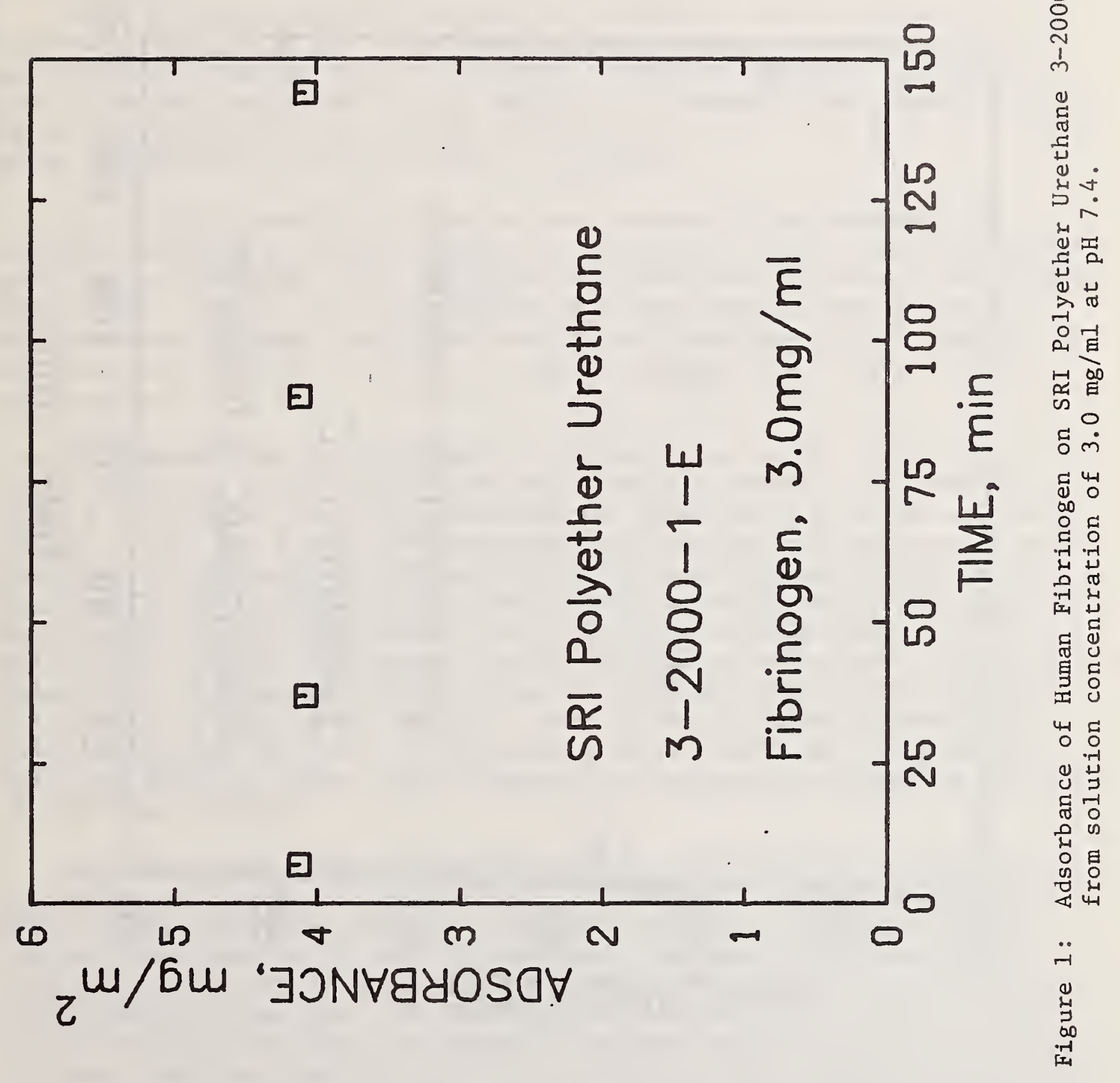




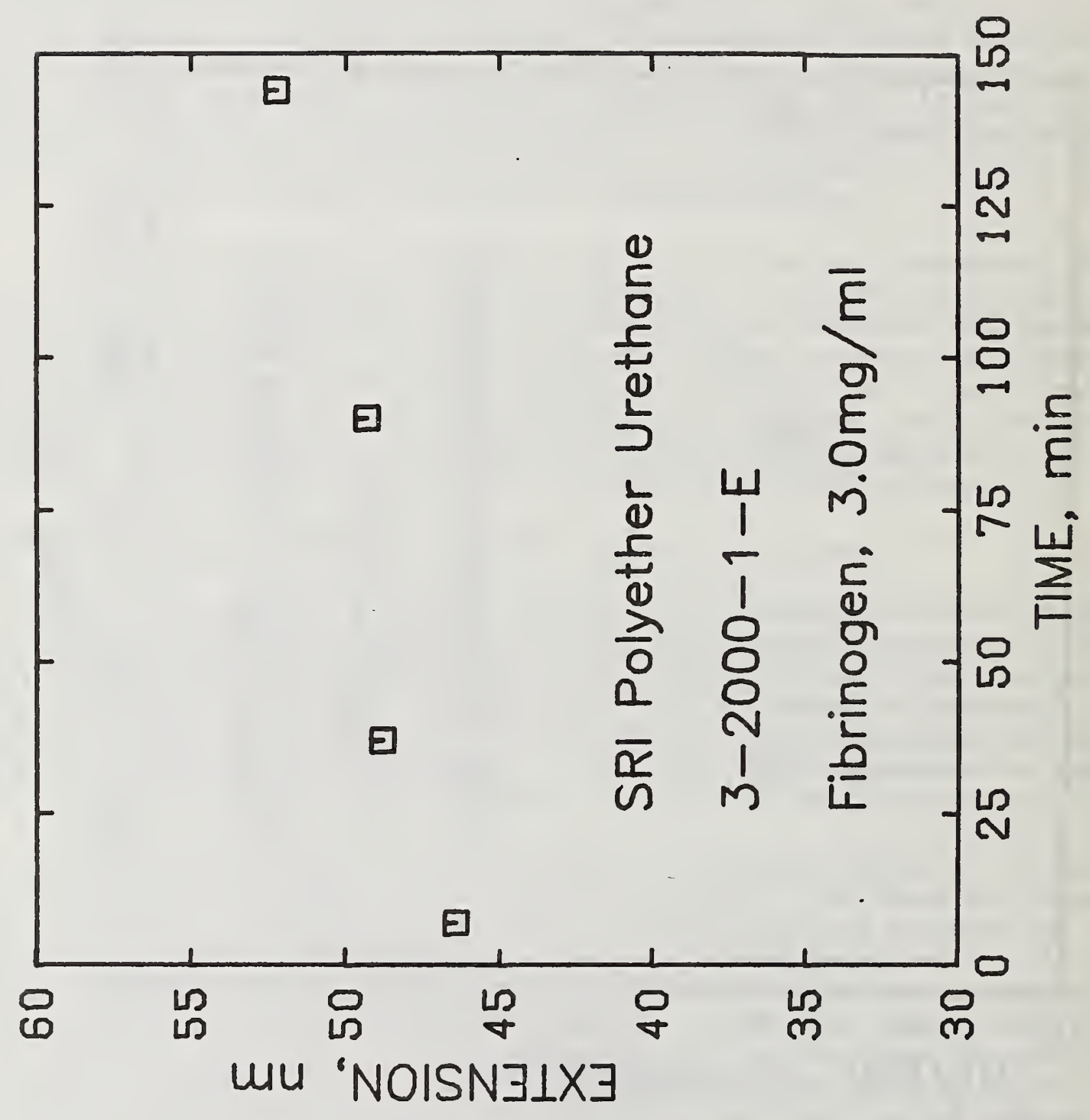

告 
The feasibility of performing quantitative ellipsometric studies of protein deposition on thinly coated substrates depends, among other things, on accurate knowledge of the refractive index of the coating. As discussed in our previous annual report (4), ion-beam deposited carbon films (Whittaker Corp.) have a significant optical adsorbance at $632.8 \mathrm{~nm}$, and for such films it is necessary to determine both the real ( $n$ ) and imaginary (k) parts of the refractive index as well as the film thickness.

From the two measured ellipsometric parameters, it is possible to determine only two of the three unknown properties of the carbon film. A more involved strategy must be employed to estimate the third quantity. One of the most sensitive of such methods is to measure the identical films on two different substrates which doubles the number of independent measurements and maintains the same number of unknowns.

During this reporting period we have measured by ellipsometry the optical constants of various samples of "ion-plated" carbon (manufacturer's notation) on stainless steel and glass, obtained from Mr. Haubold of General Atomic Corp. Two of the steel samples were reported to have $200 \mathrm{~nm}$ and $400 \mathrm{~nm}$ carbon coatings; two other samples were reported to have essentially the same (but unknown) thickness of carbon deposited on stainless steel and on glass.

We assumed that the thickness (d) values given by the supplier for two of the stainless steel samples were approximately correct. For the "400 $\mathrm{nm}^{\prime}$ film, $n$ and $k$ were found to be constant for values of $d$ in excess of about $350 \mathrm{~nm}$. Thus, for a carbon f1lm thicker than $350 \mathrm{~nm}$, the light which enters the film is all absorbed, and one obtains the same values for the optical constants of the carbon $\mathrm{film}$, whether or not the substrate optical constants are included in the calculation. For this bample, $n$ was found to be 1.75 , and $k, 0.40$. The optical parameters of the "200 $\mathrm{nm}$ " films were not substrateindependent, but the calculated values of $n(1.68)$ and $k(0.38)$ assuming the film to be exactly $200 \mathrm{~nm}$ thick, were in fairly close agreement with those of the thicker film. No substantial improvement in the agreement was found when the carbon film thickness was assumed to be somewhat greater or less than $200 \mathrm{~nm}$.

For the carbon films of unknown thickness on steel, the ellipsometric parameters were considerably different from those of either ther:200 nm or $400 \mathrm{~nm} \mathrm{film}$, indicating that the film thickness must be less than $350 \mathrm{~nm}$ and not very close to $200 \mathrm{~nm}$. Calculations indicated that a number of film thicknesses in the range 200-350 $\mathrm{nm}$ were consistent with the measured ellipsometric parameters. (No solutions were found for $d<200 \mathrm{~nm}$ ). The $\mathrm{n}$ and $\mathrm{k}$ values found for this range of thickness varied 11ttle; $\mathrm{n}$ was about 0.2 less than that found for the very thick film while $k$ was about the same as the thick film value. Thus, we find good agreement among the values of $k$ for the 3 coated steel samples, and fair agreement among the values of $n$.

Since the carbon on the glass substracte was also presumed to be 200-350 nm thick, we should have found $n$ and $k$ to be the same as for the coated steel when the calculations were performed for this range of d values. However, while $\mathrm{n}$ and $\mathrm{k}$ were found to be substrate-independent for $\mathrm{d}>210 \mathrm{~nm}$, 
the calculated $n(2.08)$ and $k(0.49)$ were both significantly higher than the values found for the very thick carbon coating on steel. Apparently, the optical constants of carbon films are not constant over a range of different sample thicknesses and different substrates. For an arbitrary carbon-coated substrate, one would have to know the thickness of the film by some independent means in order to measure the optical constants of the carbon and thus obtain the necessary information for quantitative measurements of protein deposition. For very thick carbon films, however, the optical constants can easily be determined. Therefore, such samples are suitable for protein adsorption studies.

\title{
Poly (vinyl acetate-co-crotonic acid) (Union Carbide)
}

Polypropylene plaques coated with a polyelectrolyte hydrogel, poly(vinyl acetate-co- $2 \%$-crotonic acid) $60 \%$ sodium ionomer were obtained from Dr. Lunde 11. They were found by ellipsometry to give a diffuse reflection from the surface, making accurate measurements possible. This problem could be due to surface roughness of the substrate and/or non-uniform hydrogel coating. To eliminate the first possibility, Dr. Lundell attempted to graft a hydrogel coating on to a sheet of highly reflective polyethylene supplied by us. The graft was not successful, however, apparently due to the lack of tertiary hydrogens in polyethylene.

\section{Polyacrylamide Hydrogels (Franklin Research Institute)}

Samples of vapor active monomer polymerized acrylamide on SRI Urethane (3-2000-1-E) were obtained from Dr. Kronick. The first set of samples received showed a tendency of the grafted film to "flake off" the surface. An ellipsometric examination of a subsequent sample under buffer showed almost no difference between the nominally "coated" and "uncoated" sides of the substrate. Several explanations must be considered to explain the inability to detect a film. First, a film would not be optically detected if its refractive index were essentially identical to that of the substrate. Second, if the film has coated both sides of the substrate in its preparation, the sides would be indistinguishable from each other with no "base" surface available to obtain substrate values. Third, as indicated by Dr. Kronick, it is possible that no $\mathrm{fllm}$ existed, but rather a bulk property alteration occurred as a result of acrylamide penetration during the grafting process.

\section{Glow Discharge Coatings (Research Triangle Institute)}

Girow discharge polymerized films deposited on germanium were supplied by $\mathrm{Dr}$. Yasuda. The systems chosen, acetylene $/ \mathrm{N}_{2} / \mathrm{H}_{2} \mathrm{O}$ hexamethyldisiloxane, acrylic acid, and tetrafluoroethylene were chosen to cover a range of biocompatibilities as indicated by a Lindholm clotting assay. The first set of samples were standard germanium internal reflection elements with one side coated. As these samples were too large for our cell, the films were measured in air. Given below are average values for each film.

\section{Hexamethyldisiloxane film}

\author{
Thickness $=40 \mathrm{~nm}$ \\ Refractive index $(n)=1.49$
}


Acetylene, $\mathrm{N}_{2}, \mathrm{H}_{2} \mathrm{O}$ film

Thickness $=18 \mathrm{~nm}$

Refractive index $(n)=1.66$

A second set of samples fit the ellipsometer cell and measurements were made under buffer solution. For these specimens average values are given below:

\author{
Acrylic acid film \\ Thickness $=49 \mathrm{~nm}$ \\ Refractive index $(n)=1.50$ \\ Hexamethyldisiloxane film \\ Thickness $=42 \mathrm{~nm}$ \\ Refractive Index $(\mathrm{n})=1.43$ \\ Tetrafluoroethylene Film \\ Data cannot be analyzed
}

The acrylic acid film "flaked off" the substrate and the data obtained for the tetrafluoroethylene $f 11 \mathrm{~m}$ could not be analyzed. Since only one sample remained and comparisons were not possible, protein adsorption has not yet been pursued.

\title{
RESULTS AND DISCUSSION
}

FACTORS INDUCING CONFORMATIONAL CHANGES

Applied Potent1al

The previous annual report (3) and a subsequent publication (6) have detailed the results of our study of the effect of an applied potential on the conformation of adsorbed blood protelns. The investigation of three proteins showed the existence of an anodic potential at which enhanced adsorption occurred and a cathodic potential at which a conformational change occurred as evidenced by a large increase in extension. Data obtained from a platinum substrate indicated that the potential of enhanced adsorption was dependent on the particular protein studied, although the 
data do not correlate simply with the net charge on the protein molecule.

In connection with this work, we have collected and evaluated data characterizing the relative stability of both platinum and germanium when used as substrates for in situ protein adsorption with applied potentials. The procedures followed were as previously described $(3,6)$ with the addition that germanium internal reflection elements used as substrates were cleaned with detergent, rinsed, dried, and given a two minute treatment with a glow discharge plasma unit. The immersion medium in all cases was $0.15 \mathrm{~N} N a C l$ at $\mathrm{pH} 7.4$.

As shown in Figure 3 the small drifts in the real ( $n$ ) and imaginary (k) components of the index of refraction of platinum which occurred with time were independent of either exchange of the immersion medium or applied potential. The instability of germanium, relative to platinum, was indicated by much larger changes in the ellipsometer readings and a visible etching of the surface upon removal from the system. If one ignores scattering due to roughening, the ellipsometric data can be analyzed to determine the apparent optical constants of germanium in the presence of $0.15 \mathrm{~N} \mathrm{NaCl}$. The reflection coefficients, $r^{\perp, \|}$, can be used to calculate the optical density per reflection, $O D^{\perp, 11}=-2$ log $\mathrm{r}^{\perp, 11}$. Large changes in the apparent optical density of germanium as a function of both the immersion time and the applied potential are shown in Figures 4 and 5 . The similar analysis in terms of optical densities for the platinum data of Figure 3 yields a variation in ${ }^{1}$ and $O D^{\prime \prime}$ of from 0.062 to 0.059 and 0.402 and 0.394 , respectively. If errors observed at visible wavelength carry over into infrared wavelengths, the etching could also produce artifacts in internal reflection measurements of protein adsorption on germanium. The observed ATR intensities would be unpredictably increased by these artifacts. Unfortunately, these artifacts cannot be accounted for in control experiments since the Drude model required for data analysis is no longer valid. Obviously such artifacts preclude the use of the Drude equations either for ellipsometry or internal reflection spectroscopy in such a system.

\section{Surface Concentration}

The adsorption of clotting factors and proteins on the surface of a synthetic implant can modify both their biological activity (7-9) and the subsequent interfaction of formed cellular elements (10) with the surface. As has been noted (11), the amount adsorbed and composition of adsorbed protein films do not account for the variation in biocompatibility observed for some materials. Additional details, in particular the adsorbed conformation, are apparently required to characterize materials and rationalize the effect of blood-surface interactions. It has been assumed $(12,13)$ that adsorbing proteins initially arriving at a surface unfold to occupy a large number of available surface adsorption sites resulting in a denaturation at the solid/solution interface. The inapplicability of this assumption to all cases has been demonstrated by recent studies of adsorbed serum albumin and prothrombin $(4,14)$ which indicated no change in conformation as the surface concentration increased.

Two separate methods are available for changing surface population, time and solution concentration. In order to directly determine the existence and extent of conformational changes in adsorbed proteins due to mutual interaction 


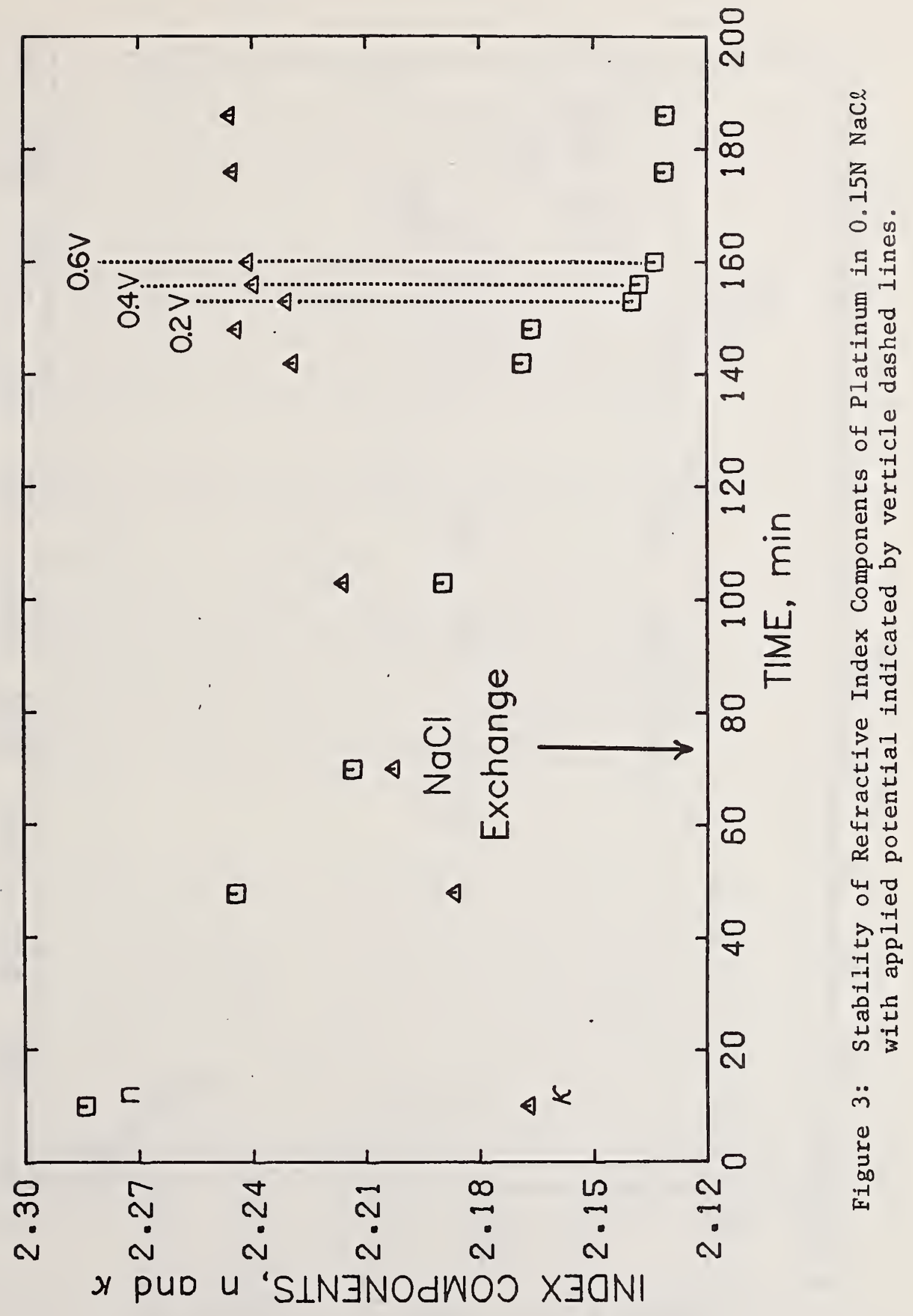




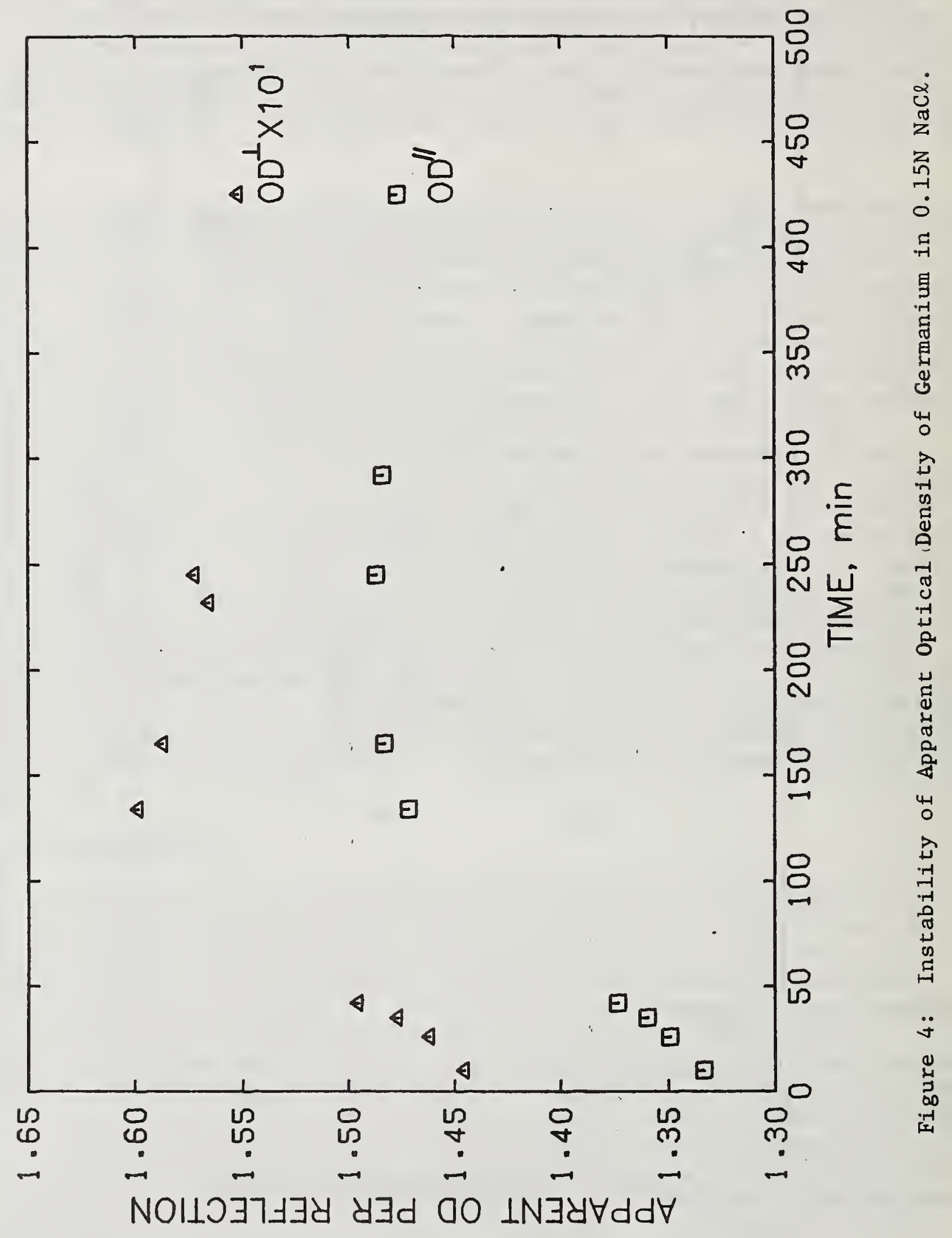




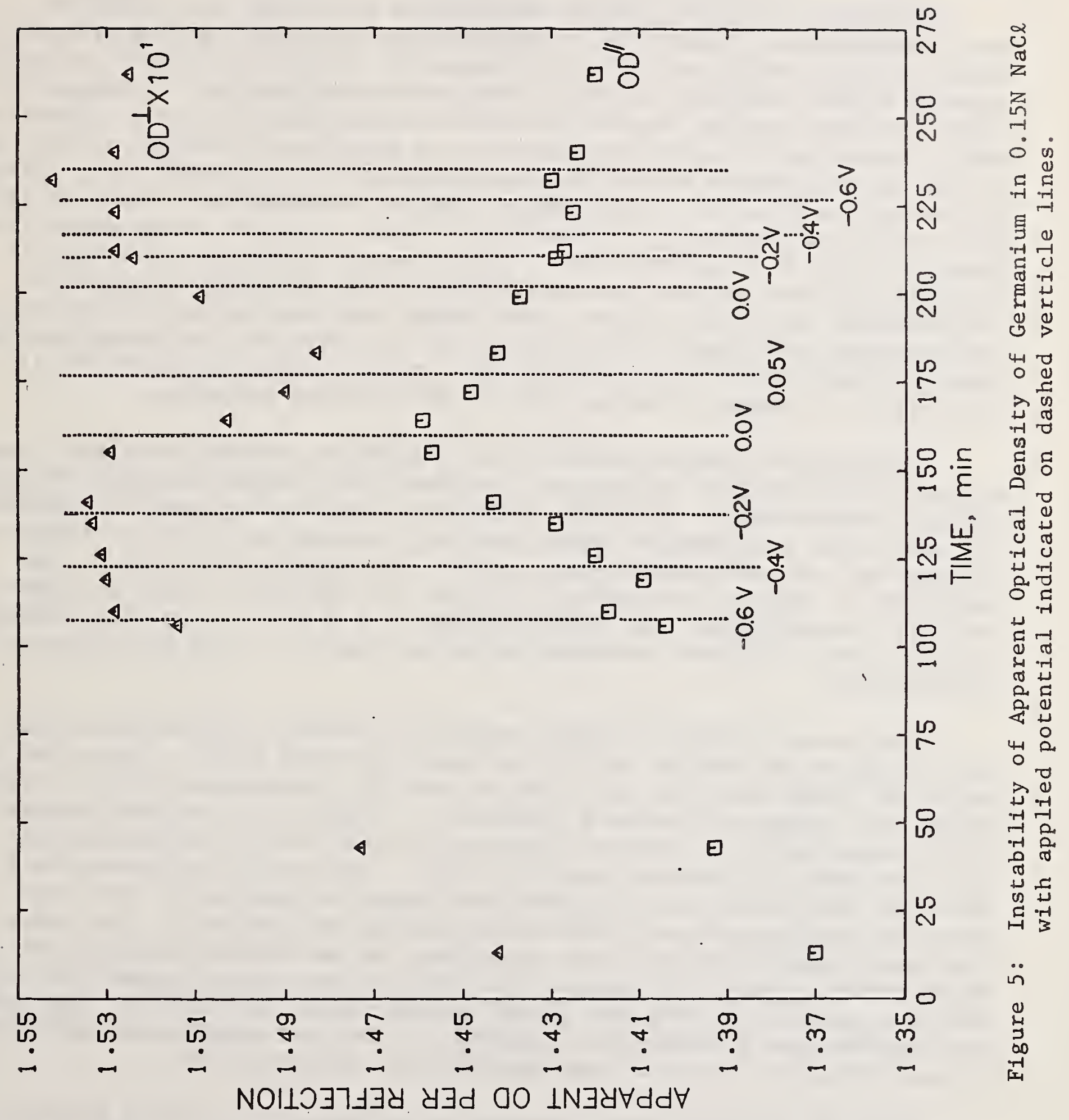


at the interface, in situ infrared bound fraction and ellipsometric studies have been carried out to characterize the adsorption of $\gamma-g l o b u l i n$ and $\beta-1$ actoglobulin on silica. Through studies of the properties of native and crosslinked $\gamma$-globulin, one can determine the correspondence between adsorbed and solution conformation, and thereby directly obtain a measure of surface "denaturation".

Although most of the results obtained in this study were presented in our previous annual report (3), some additional work was carried out during this reporting perlod and recent ellipsometric results for native $\gamma-g l o b u l i n$ adsorption have slightly modifled those previously reported. To summarize those reported results, the bound fraction measurements for both $\gamma-g$ lobulin and $\beta$-lactoglobulin showed that there was a significant decrease in the number of surface attachments as the surface concentration increased. For $\gamma-g l o b u l i n$, the change was from 165 to 30 carbonyl surface attachments as shown in Table I, while for $\beta$-lactoglobulin, the decrease in bound fraction corresponded to a change of from 30 to approximately 2 attachments. Bound fraction results obtained for serum albumin and prothrombin $(4,14)$ indicated no change in conformation for either protein, even though both have elliptical solution conformations with large axial ratios. It is, therefore, unlikely that the observed trend in the bound fraction of $\gamma$-globulin or $\beta$-lactoglobulin is due merely to changes in orientation of the adsorbed molecules.

El11psometric results obtalned for $\gamma$-globulin adsorbed on planar fused sllica provide further evidence of conformational changes dependent on the surface concentration. As shown in Figure 6 , adsorbed $\gamma$-globulin achieves a steady state conformation rather quickly, although material continues to be adsorbed over an extended time period. As indicated in Table I, the extension of adsorbed $\gamma$-globulin is higher for adsorption from the higher solution concentration. At concentrations of 0.3 and $10.0 \mathrm{mg} / \mathrm{ml}$, extensions of $14 \pm 3 \mathrm{~nm}$ (calculated standard deviation) and $32 \pm 11 \mathrm{~nm}$ were observed, respectively.

The protein extension values reported in Table I were obtained from the ellipsometric data by use of the Drude equations $(4,15)$. The model upon which the Drude equations are based is that of a homogeneous film of constant refractive index with discrete boundaries. However, the adsorbed protein film, consisting of a mixture of protein and solvent is not homogeneous, and therefore will deviate from this model. The protein concentration in the film, and hence the refractive index would be expected to vary with distance from the surface, probably decreasing monotonically. The use of the Drude equations will result, therefore, in an average extension value which would be about $50 \%$ greater than the root-mean-square segment to surface distance calculated using the actual concentration distribution. The technique for relating the ellipsometric thickness to the root-mean-square extension in any particular case has been described by McCrackin (16).

Both the infrared bound fraction and ellipsometric results presented above indicate the presence of lateral interactions between adsorbed molecules of $\gamma$-globulin and $\beta$-lactoglobulin. It is of interest to note, however, that a Langmulr plot $\left(C_{b} / C_{s}\right.$ vs. $C_{b}$ where $C_{b}=$ equilibrium solution concentration and $\mathrm{C}_{\mathrm{s}}=$ the surface concentration) of the adsorption data obtained for both proteins adsorbed on divided silica, resulted in good linear correlations for $C_{b} \geq 0.1 \mathrm{mg} / \mathrm{ml}$. Since lateral interactions have been demonstrated 
TABLE I

$\gamma$-Globulin Adsorbed on Silica

\begin{tabular}{|c|c|c|c|c|}
\hline $\begin{array}{l}\text { Conc. } \\
\mathrm{mg} / \mathrm{ml}\end{array}$ & $\begin{array}{c}\text { Adsorbance } \\
\mathrm{mg} / \mathrm{m}^{2} \\
\end{array}$ & $\begin{array}{l}\text { Bound } \\
\text { Fraction }\end{array}$ & $\begin{array}{l}\text { No. Carbony } 1 \\
\text { Attachments } \\
\end{array}$ & $\begin{array}{c}\text { Extension } \\
\mathrm{nm}\end{array}$ \\
\hline 0.30 & $1.8 \pm 0.8$ & 0.12 & 165 & $14 \pm 3$ \\
\hline 10.0 & $3.4 \pm 0.6$ & 0.02 & 30 & $32 \pm 10$ \\
\hline
\end{tabular}

\section{DEM Crosslinked}

$\begin{array}{llll}0.30 & 2.2 \pm 0.6 & 0.06 & 21 \pm 7 \\ 10.5 & 2.1 \pm 0.6 & 0.01 & 20 \pm 8\end{array}$




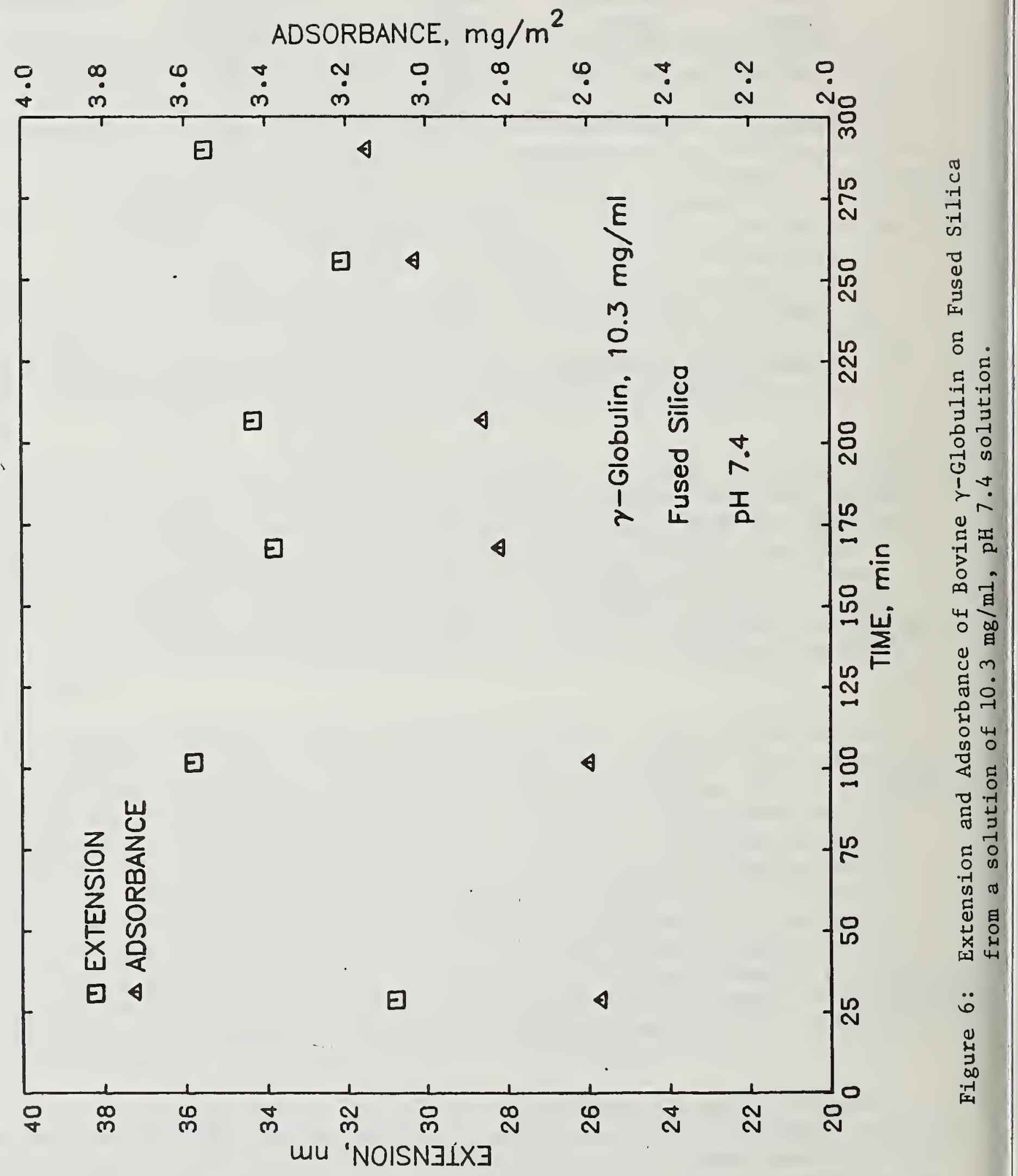


experimentally, the consistency with the prediction based on the Langmuir model must be considered fortuitious. The use of the Langmuir equation to determine the presence or absence of lateral interactions should be viewed with skepticism.

Previous bound fraction and ellipsometric studies (3) of the adsorbed conformation of $\gamma$-globulin cross-1inked with diethyl malonimidate hydrochloride indicated that the adsorbed conformation corresponding to the "native" conformation in solution was intermediate between high and low surface concentration. The adsorption isotherm for native $\gamma$-globulin lies above that for the cross-linked material and rises more steeply, even though both isotherms have approximately the same plateau adsorbance. It, therefore, appears that adsorbed native molecules can apparently rearrange on the surface to minimize interactions which results initially in a higher adsorbance and a sharper break in the 1sotherm as it approaches the plateau value.

Thus, comparison of the bound fraction and ellipsometric results for native and cross-linked $\gamma$-globulin ( $\mathrm{Table} I$ ) indicates that there are distortions of the native conformation at both low and high adsorbance. At low surface concentration, lack of competition for surface adsorption sites results in a flatter adsorbed conformation, while at high surface concentration, repulsions cause a more extended conformation with fewer surface attachments. Adsorbed $\gamma$-globulin would, therefore, appear to be rather pliant, underscoring the importance of defining the adsorbed conformation when carrying out macroscopic measurements of surface-cellular interactions in thepresence of proteins.

\section{Adsorption Time}

A second means of changing surface population, time of adsorption, although more difficult to achleve, should provide considerable additional insight into the adsorption mechanism. Because of instrumental limitations, our previous ellipsometric studies of proteln adsorption have been limited by the inability to observe these early steps in the adsorption process. It is impossible to make meaningful measurements if the optical properties of the film are changing on the time scale of a single measurement, which is likely to be the case for the early stages of protein adsorption.

We have recently obtained an automatic ellipsometer with which one can simultaneously measure at very short time intervals two parameters which define the state of the elliptically polarized 11ght reflected from a surface. These parameters, aximuth $(\alpha)$ and ellipticity $(\varepsilon)$, are easily converted into the more familar reflection parameters $\Delta$ and $\psi_{\text {. }}$ By use of the Drude equations $(3,15)$ we can calculate the thickness, refractive index, and adsorbance of a protein film. Since the instrument is capable of measuring $\alpha$ and $\varepsilon 54$ times per second, it is possible to observe very rapid changes in the parameters.

Several protein adsorption experiments using platinum as the substrate have been performed to date with the automatic ellipsometer. As yet, none of the experiments has been repeated and the results must be regarded as preliminary and tentative. Human fibrinogen $(2.5$ and $0.42 \mathrm{mg} / \mathrm{ml}$ ) and bovine $\gamma$-globulin $(12.2,0.22$ and $0.044 \mathrm{mg} / \mathrm{ml})$ were separately adsorbed onto clean 
platinum slides according to the method described in the Experimental section. For the most concentrated $\gamma$-globulin solution, essentially all of the change in the ellipsometric parameters occurred by the time of the first observation, approximately $2 \mathrm{~s}$ following the introduction of the solution. For each of the other protein solutions, however, significant changes in $\alpha$ and $\varepsilon$ occurred during the first minute of observation, and smaller changes occurred during the next hour.

Selected points along the recorder tracings of $\alpha$ and $\varepsilon$ vs. time were used to compute the film thickness and adsorbance. Almost all of the data points could be analyzed to give reasonable values of molecular extension and adsorbance. In each case, the calculated protein adsorbance increased during the total time of observation, with a large fraction of the total increase occurring during the first minute. In all cases but one, the calculated film thickness (molecular extension) remained essentially constant throughout the run. The one exception to this, the $0.42 \mathrm{mg} / \mathrm{ml}$ fibrinogen solution, indicated a large increase in the film thickness during the first minute, and an equally large further increase during the next 2 hours. Since there are experimental artifacts which could cause this type of behavior, this result must be regarded as highly questionable, pending replicate experiments. Nevertheless, our initial experiments with the automatic ellipsometer indicate that the technique can provide much information about the kinetics of polymer film deposition on surfaces.

\section{Denaturing Media}

As observed in our radiotracer studies, adsorbed protein desorbs very slowly, if at all, from polyethylene. This "irreversible" behavior on the hydrophobic polymer surface contrasts strongly with the highly reversible adsorption on silica, a typical high energy surface. These findings are somewhat surprising since previous ellipsometric studies (4) have shown that the extension of an adsorbed protein is greater on low energy than on high energy surfaces. If one assumes that the extension and bound fraction are inversely related, as observed for some synthetic polymers, then a protein adsorbed on polyethylene should have fewer attachments and desorb more rapidly. This irreversible adsorption on polyethylene suggests, however, the existence of a larger number of surface attachments or a higher segment-surface interaction energy. To clarify the cause of the lack of desorption, as well as to gain an insight into protein adsorption mechanisms, an ellipsometric study of the effect of a strong denaturing agent, urea, on $\gamma$-globulin and fibrinogen adsorbed on polyethylene was undertaken. Measurements were carried out using $0.1 \mathrm{M}$ phosphate buffer at $\mathrm{pH} 7.4$ and buffered $8 \mathrm{M}$ urea.

The results given in Figures 7 and 8 for the adsorbance and extension of fibrinogen on polyethylene are typical. Adsorption is fast and virtually complete at the time of the first measurement and an extension of $30 \mathrm{~nm}$ is attained in each case. Exchange of the protein solution for buffer induces no significant changes in the adsorbance or conformation of elther fibrinogen or $\gamma$-globulin. The further exchange of buffer for buffered $8 \mathrm{M}$ urea, however, results in a large increase in extension of both $\gamma$-globulin and fibrinogen as shown in Figure 8 for fibrinogen. Some of this increase may result from the large refractive index difference between the urea and buffer solutions. However, a significant increase in extension does occur even after taking this into account. 


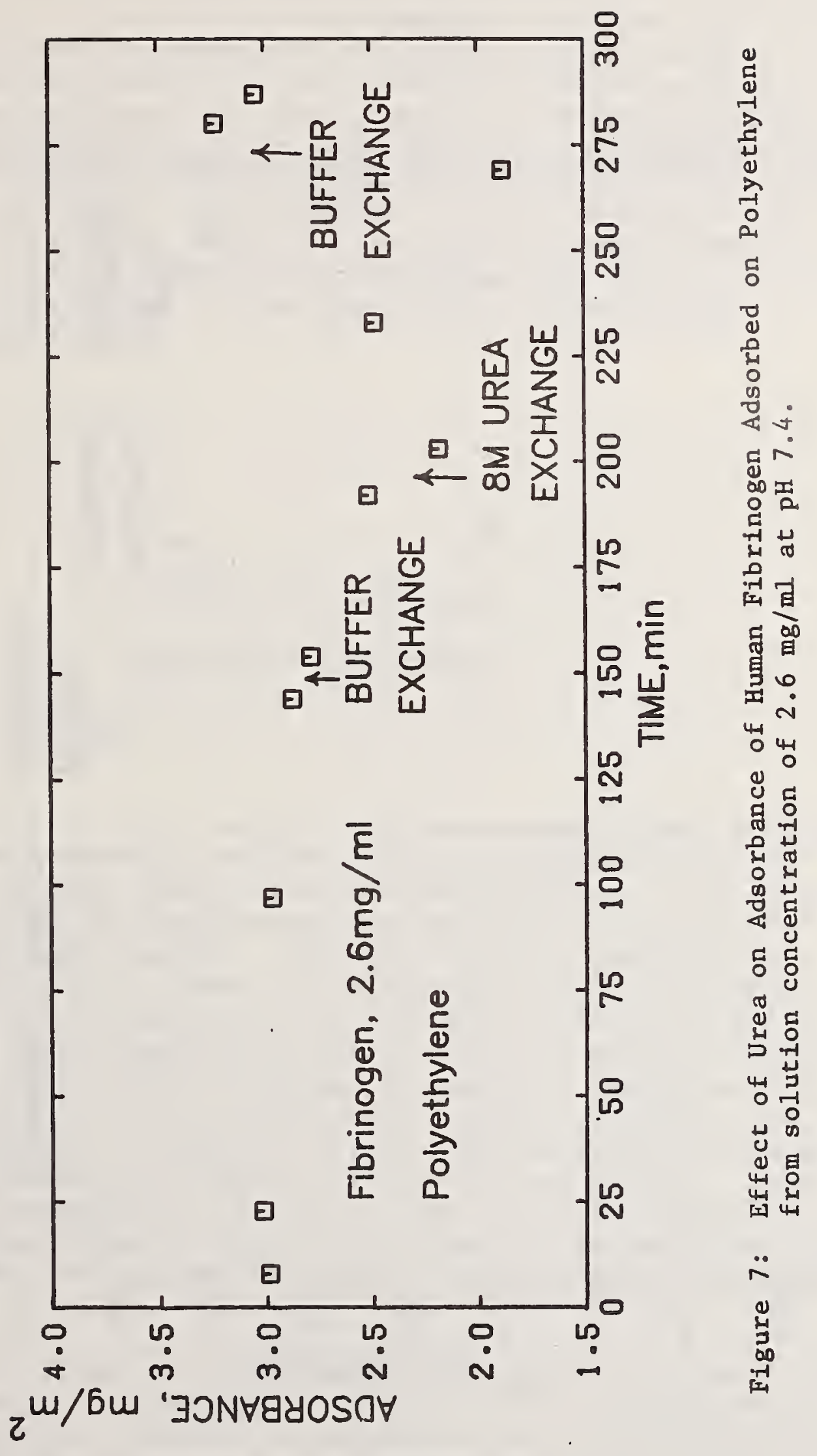




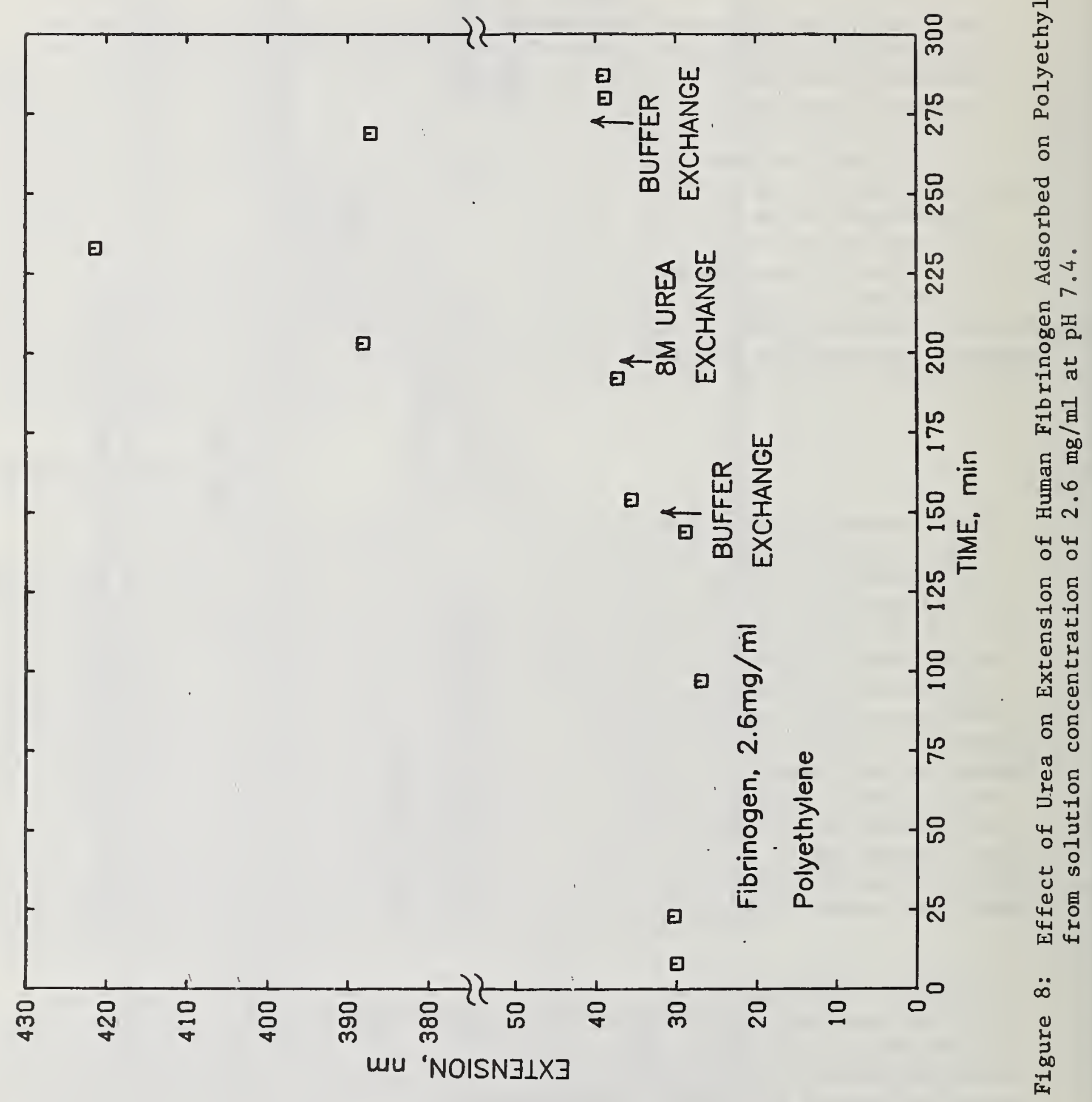


The high protein adsorbance on polyethylene, even somewhat higher than that on silica, and especially the "irreversible" nature of the adsorption, may be important considerations when designing polymeric implant devices. The higher adsorbance of $\gamma$-globulin when adsorbed on polyethylene compared to silica is not inconsistent with the finding that the extension in general increases with decreasing surface energy. If increased extension correlates with fewer surface attachments, then the reduced area per adsorbed molecule could result in a higher adsorbance. The inability to desorb fibrinogen and $\gamma$-globulin from polyethylene into buffer or $8 M$ urea indicates a strong interaction with the surface. The large increase in extension, and presumably the large decrease in the number of surface attachments, which occurs during attempted desorption into urea solution implies that strong hydrophobic bonding, and not a large number of surface attachments, is the cause of the "irreversible" adsorption on polyethylene.

RESULTS AND DISCUSSION

RADIOTRACER RATE STUDIES

Measurement

Some of the factors which contribute to measurement errors associated with the use of radiotracers to measure protein adsorption have been identified (17). We have observed that the incorporation of a radioactive element into a protein for labeling purposes may result in artifacts that are not immediately apparent. The use of such a label for the measurement of adsorption is based on the assumption that the labeled material is essentially identical in its adsorption behavior to the nonlabeled material. This assumption may be in error for several reasons. First, adsorption of the label itself may dominate the adsorption process and this effect may vary from one surface to another. Secondly, the presence of the label in the protein or the method employed to incorporate the label may significantly alter the structure of the protein. Thirdly, the effect of any impurities in the small volume of labeled material may be multiplied many times if there is a large dilution with non-labeled materials. Our data indicate that all three of these factors are important for some systems.

We have noted a marked difference among the adsorption values of HSA depending on the method of labeling. The use of $125 \mathrm{I}$, introduced by the ICl method in our laboratory, resulted in adsorbance values on polyethylene considerably higher than observed for HSA commercially labeled with $131_{\text {I. }}$. When undiluted 125 I labeled HSA tagged by the above method was adsorbed on silica or polyethylene, an adsorbance of approximately $5 \mathrm{mg} / \mathrm{m}^{2}$ was observed. However, when the same solution is diluted by a factor of 1:200 with nonlabeled HSA, an adsorbance of approximately $30 \mathrm{mg} / \mathrm{m}^{2}$ was observed. This 
dilution effect (higher adsorbance for the diluted-labeled system) seems to be responsible for the higher adsorbance found by others (18) using McFarlane's ICl method to label fibrinogen and subsequently diluting it with non-labeled fibrinogen by factors of $1: 100$ and $1: 50$.

Commercially labeled HSA with 125 I as the labeled atom also gave adsorption values several times higher than those reported for $13 \mathrm{I}_{\mathrm{I}}$, but lower than that obtained for the ICl labeled sample. Although the adsorbances were different, reproducibility for each sample was excellent, both for run to run using the same batch of labeled protein as well as for batch to batch. The commercial materials may be quite sultable for the diagnostic purposes for which they were prepared, but the protein may be altered from the native material in a way that affects its adsorptive behavior. There are several possible causes for these differences, but the most likely is aggregation of the protein during the labeling procedure followed by incomplete purification.

We have previously shown (3) that HSA labeled with ${ }^{131}$ I and adsorbed on platinum produced high apparent adsorbance values for that particular system which resulted from the specific adsorption of the labeled species. This artifact was first suggested by the fact that the measured adsorbance was not independent of the concentration of the labeled species even when the total protein concentration was not changed. Such a study was conducted for HSA labeled with 125I and adsorbed on polyethylene. Table II gives the measured adsorbance of HSA as a function of the amount of radio-labeled protein present. In the absence of specific adsorption, or if the specific adsorption is always proportional to the concentration of that species alone, there would be no change in adsorbance with activity. This surface. is, therefore, free of this artifact.

\section{Desorption and Exchange}

In spite of some uncertainty in the adsorbance values estimated using different radiolabeled species, desorption and exchange rates might be valid when expressed as functions of the plateau adsorbance measured for that particular system. This indeed seems to be the case for HSA adsorbed on polyethylene as the desorption and exchange results are independent of the labeled spectes or the activity of the label. As shown in Figure 9 , there is virtually no desorption or exchange of adsorbed protein with protein in solution in this system, even after 25 hours. This finding can be contrasted to previous results for the displacement of serum albumin from chromium as shown in Figure 10, which showed marked decreases in the amount of adsorbed HSA as a function of time. These results suggest, as discussed earlier in this report, that there is either a more uniform distribution of energy sites on the low energy surface which results in a larger number of surface attachments per adsorbed molecule, or that the segment interaction energy resulting from hydrophobic bonding is considerably greater than that resulting from hydrogen bonding as envisioned for protein adsorption to a chromium surface.

In contrast to the ellipsometric results on fibrinogen and $\gamma$-globulin described earlier, desorption of HSA 125 I from polyethylene into $8 M$ urea resulted in the removal of approximately one-half of the protein as shown in Figure 11. 
TABLE II

Apparent Adsorbance as a Function of Specific Activity of HSA- ${ }^{125}$ I Solution

Relative Activity

Polyethylene

Surface

$\mathrm{mg} / \mathrm{m}^{2}$

1.00

32

0.67

33

0.50

33

0.33

41

0.25

34

0.20

31 


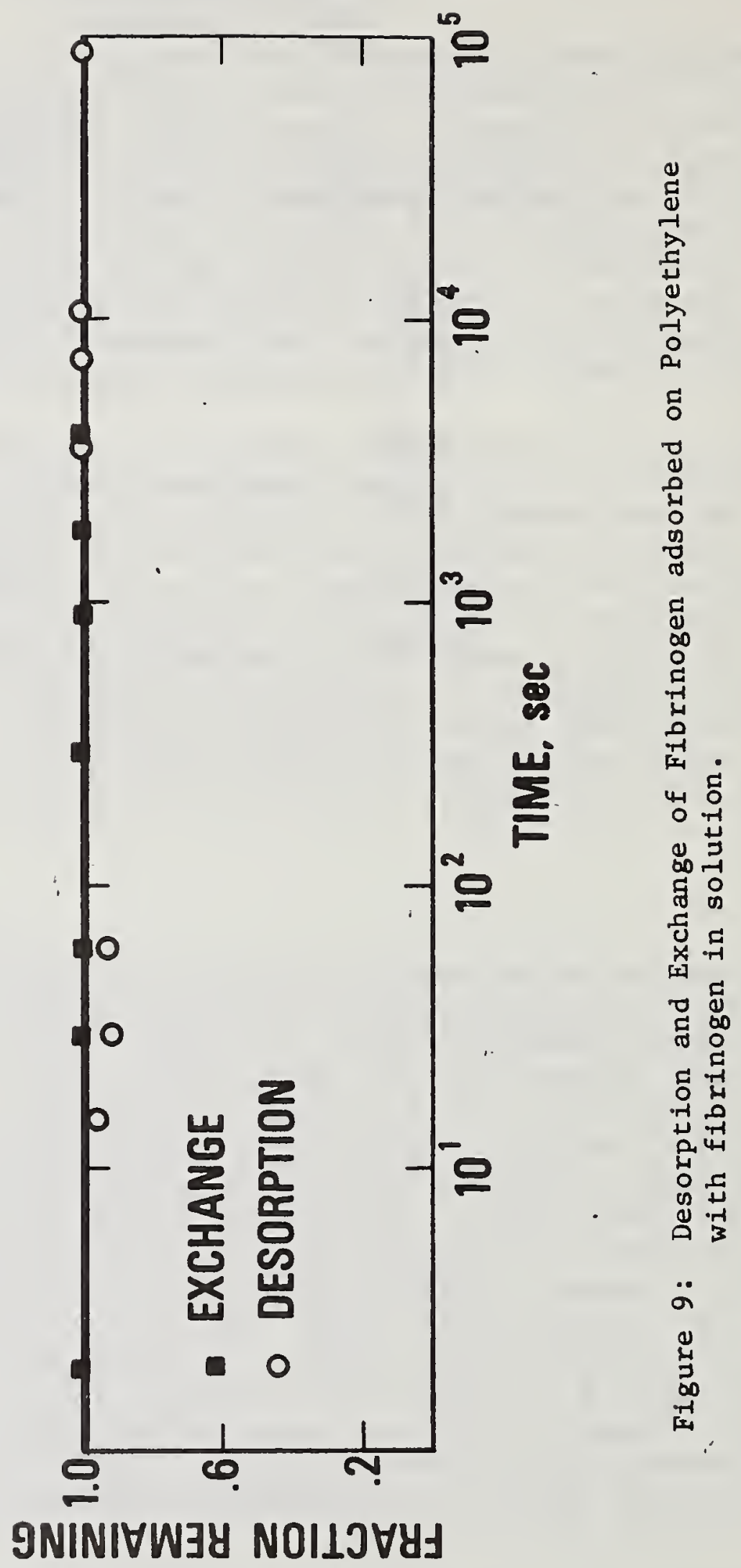




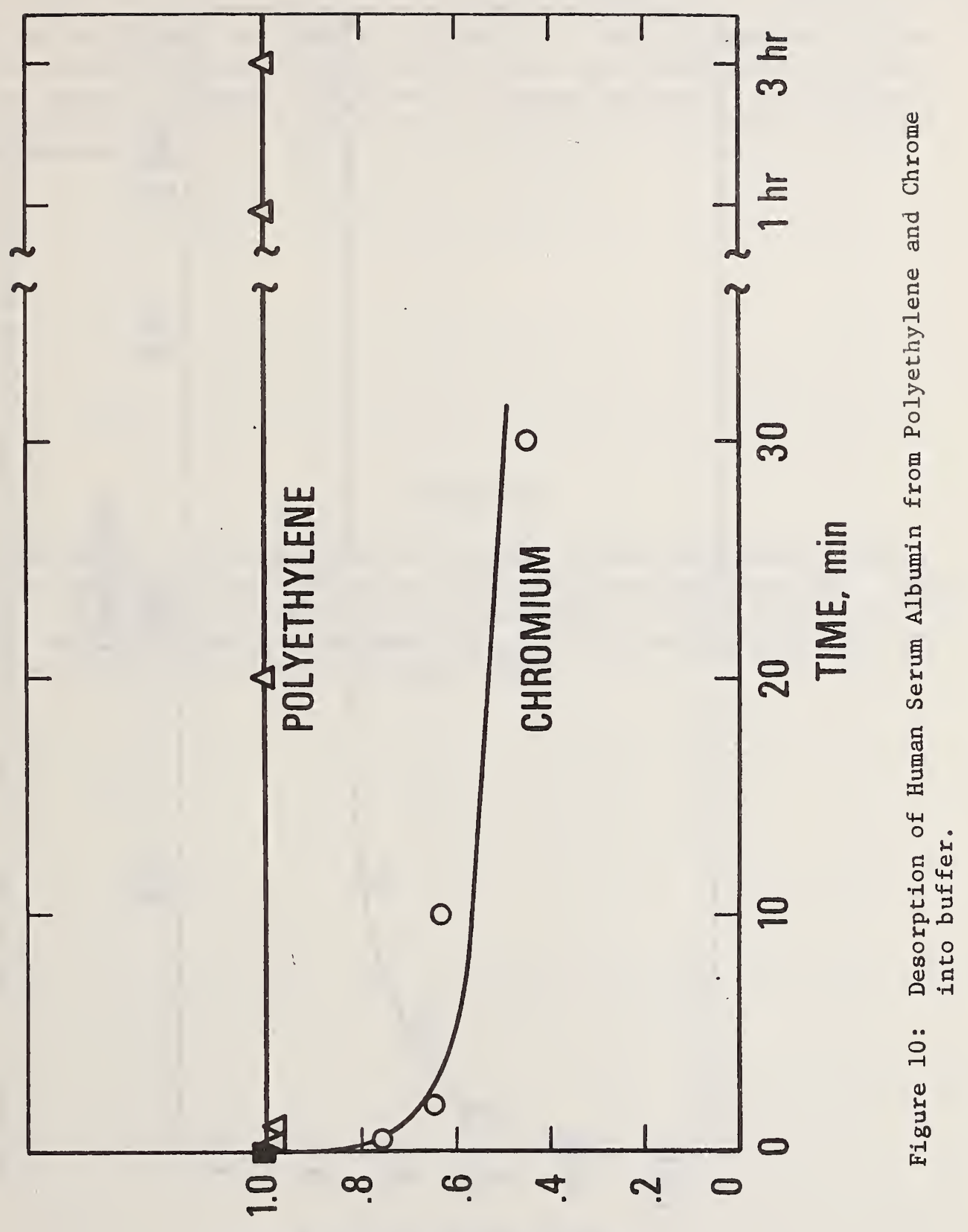

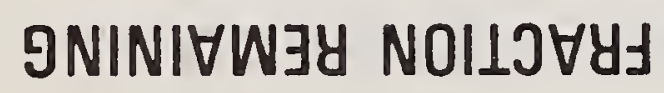




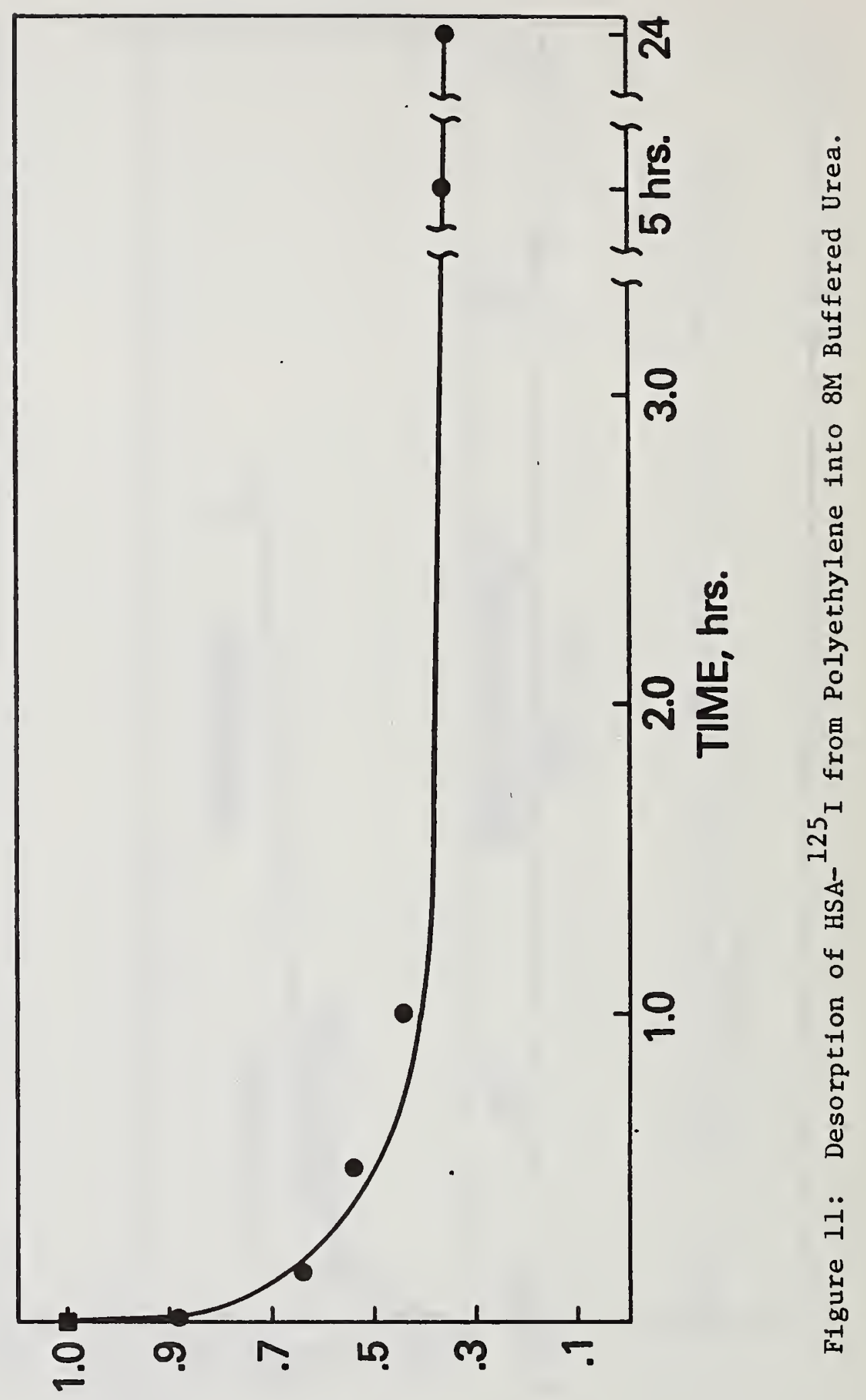

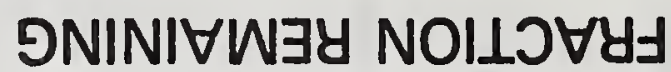




\section{Silicone Rubber}

Measurements of $\mathrm{HSA}^{131}$ I adsorbance on silicone rubber (non-reinforced medical grade Silastic, Dow Corning) shown in Figure 12 indicates that the time required to attain apparent equilibrium adsorbance is considerably slower than the ten seconds required for chrome (3). The differences in rates to plateau values may be related to the surface free energy, $1 . e .$, as the surface energy increases, the times to plateau decrease. An increase in the extension with decreasing surface energy has been noted for several blood proteins (4).

\section{DISCLAIMER}

This report was prepared as an account of work sponsored by the National Heart and Lung Institute. It is not to be construed as a report, opinion, or recommendation of the National Heart and Lung Institute. It will be available from the National Technical Information Service, 5285 Port Royal Road, Springfield, Virginia 22151. 


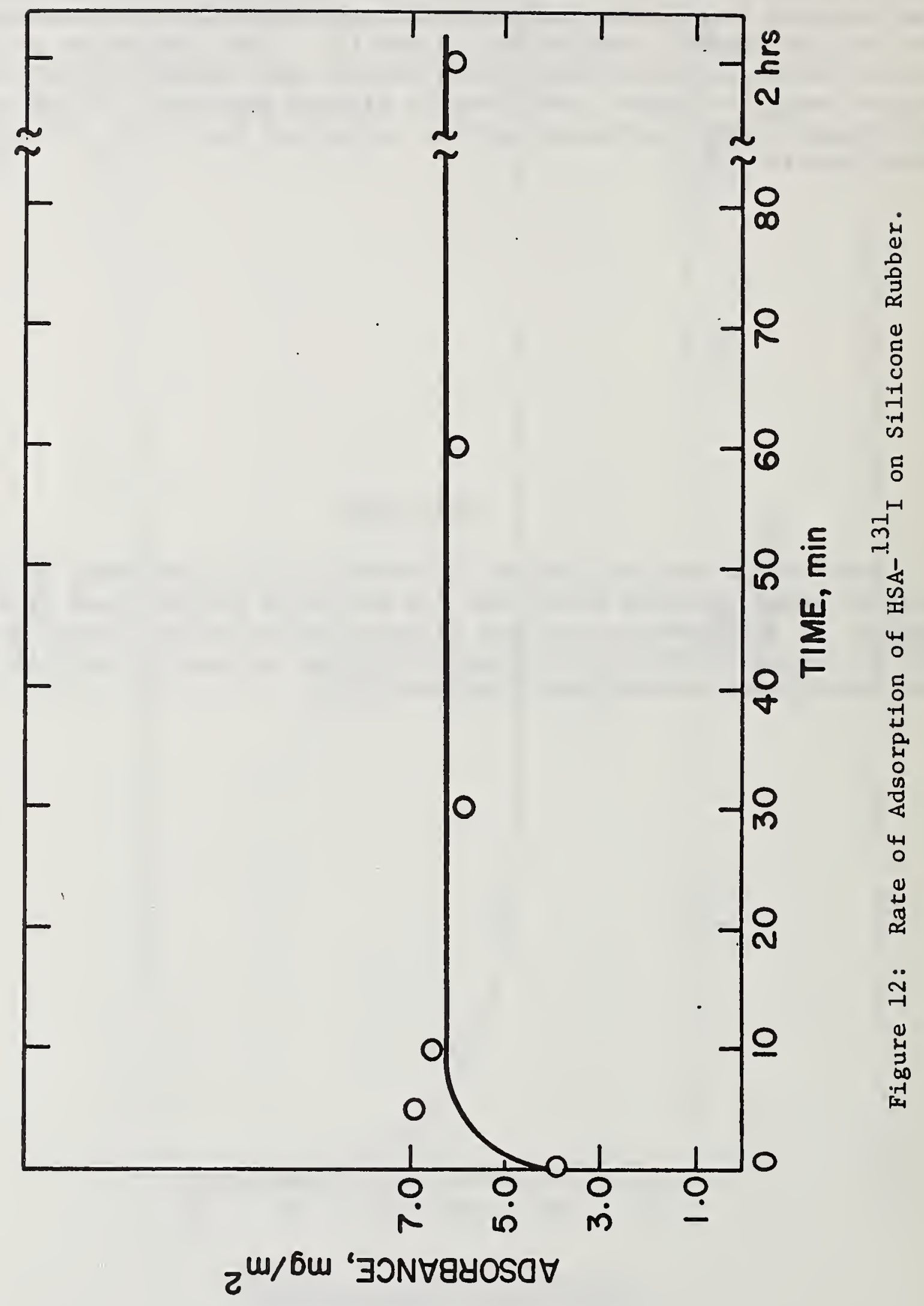


1. Laki, K., Arch. Biochem. Biophys., 32, 317 (1951).

2. Batt, C. W., Mikulka, T. W., Mann, K. G., Guarracino, C. L., Altiere, R. J., Graham, R. G., Quigley, J. P., Wolf, J. W., and Zafonte, C. W., J. B1ol. Chem., 245, 4857 (1970).

3. Stromberg, R. R., Morrissey, B. W., Smith, L. E., Grant, W. H., and Fenstermaker, C. A., "Interaction of Blood Proteins with Solid Surfaces", PB 241 267/4SL (Available from the National Technical Information Service), Annual Report prepared for the Biomaterials Program, National Heart and Lung Institute, NIH, Bethesda, Md., January 1975.

4. Fenstermaker, C. A., Grant, W. H., Morrissey, B. W., Smith, L. E., and Stromberg, R. R., "Interaction of Plasma Proteins with Surfaces", PB 232 629/6 (Available from the National Technical Information Service), Annual Report prepared for the Biomaterials Program, National Heart and Lung Institute, NIH, Bethesda, Md., March 1974.

5. McFarlane, A. S., Nature, 182, 53 (1958).

6. Morrissey, B. W., Smith, L. E., Stromberg, R. R., Fenstermaker, C. A., to be published in J. Colloid and Interface ScI.

7. Gitel, S. N., Owne, W. G., Esman, C. T., and Jackson, C. M., Proc. Nat. Acad. Sci. USA, 70, 1344 (1973).

8. Waugh, D., Anthony, L. J., and Ng, H., J. Blomed. Mater. Res., 9, 511 (1975).

9. Margolis, J., Aust. J. Exp. Biol., 39, 249 (1961).

10. Mohandas, N., Hochmuth, R. M., and Spaeth, E. E., J. Biomed. Mater. Res., 8, 119 (1974).

11. Horbett, T. A., and Hoffman, A. S. in "Applied Chemistry at Protein Interfaces", (R. E. Baier, Ed.) Advances in Chemistry Series No. 145, American Chemical Society, Washington, D. C. (1975).

12. Baier, R. E., Loeb, G. I., and Wallace, G. T., Fed. Proc., 30, 1523 (1971).

13. MacRichie, F., J. Colloid Interface Sci., 38, 484 (1972).

14. Morrissey, B. W., and Stromberg, R. R., J. Colloid Interface Sc1., 46, 152 (1974).

15. Drude, P., Ann. Physik, 272, 532 (1889); 272, 865 (1889); 275, 481 (1890).

16. McCrackin, F. L., and Colson, J. P., in "Ellipsometry in the Measurement of Surfaces and Thin Films", Symposium Proceedings, NBS Misc. Publ. 256, Washington, D. C. 20234, p. 61 (1964). 
17. Grant, W. H., Smith, L. E., and Stromberg, R. R., to be published.

18. Leonard, E. F., Kochwa, S., Litwak, R. S., and Rosenfield, R. E., "Coordinated Studies of Platelet and Protein Reactions on Artifical Materials", PB 241 333/4SL (Avallable from the National Technical Information Service), Annual Report prepared for the Biomaterials Program, National Heart and Lung Institute, NIH, Bethesda, Md. 20014 October 1974. 


\section{BIBLIOGRAPHIC DATA} SHEET

3. Recipient's Accession No.

4. Title and Subritle

INTERACTION OF BLOOD PROTEINS WITH SOLID SURFACES

7. Author(s) R. R. Stromberg, B. W. Morrissey, L. E. Smith,

W. H. Grant, and R. E. Dehl

9. Performing Organization Name and Address

Polymers Division

Institute for Materials Research

National Bureau of Standards

Washington, D. C. 20234

2. Sponsoring Organization Name and Address Biomaterials Program

Devices and Technology Branch

Division of Heart and Vascular Diseases

NATIONAL HEART AND LUNG INSTITUTE

Bethesda, Maryland 20014

15. Supplementary Notes

\section{Abstracts}

The overall objective of this investigation is to help characterize materials used for implants in the cardiovascular system and to develop test methods to ald in the selection of the most useful materials. The focus of the work has been an investigation of the adsorption of blood proteins on surfaces with special emphasis on changes in conformation occurring upon adsorption. An important component has been an ellipsometric examination of materials produced by contractors of the NHLI Biomaterials Program that were considered to be of potential clinical value. In contrast to the behavior of serum albumin and prothrombin, conformational changes in $\gamma$-globulin and $\beta-1$ actoglobulin occurring as a consequence of changing surface population were previously reported and were confirmed during this reporting period. An investigation of conformational changes at very short adsorption time was initiated. Adsorption, desorption and exchange of adsorbed protein in solution was studied. The results indicate strong hydrophoblc bonding between the protein and the 17. Key Words and Document Analysis. 17a. Descriprors synthetic polymer surface.
Adsorption
Blood protein
Bound fraction
Ellipsometry
Implants
Polymer adsorption
Protein adsorption
Synthetic implants

7b. Identifiers/Open-Ended Terms

7c. C.OSATI Field/Group

\section{8.} Releasable to the public. Order from: National Technical Information Service 5285 Port Royal Road Springfield, Virginia 22151 


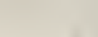

